\section{Factors Influencing Intake of Mineral Supplements by Cattle on Southern Forest Range ${ }^{1}$}

\author{
V. L. DUVALL AND L. B. WHITAKER \\ Assistant Director and Range Technician, Southern \\ Forest Experiment Station, USDA, Forest Service, \\ New Orleans and Alexandria, Louisiana.
}

\section{Highlight}

Among cattle fed cottonseed cake daily in winter, salt and bonemeal consumption was greater on moderately grazed range ( $48 \%$ utilization) than on ranges grazed either lightly $(32 \%)$ or heavily $(57 \%)$. Cattle on heavily grazed range ate much less bonemeal than others. On ranges grazed moderately, cattle fed cake on alternate days in winter consumed the most salt from ad libitum supply and also ate the most bonemeal. Cattle self-fed a cottonseed meal-salt mixture ranked second in bonemeal consumption and lowest in voluntary intake of salt. Total salt eaten annually by these animals was much greater than for those fed protein supplement by other methods, however, and voluntary intake continued yearlong, even though the ration furnished far more salt than needed in winter.

\section{Resumen}

El estudio se llevó a cabo en el estado de Louisiana en un pastizal de Andropogon tener y Andropogon divergens, comprendiendo como potreros pastoreados con vacas todo el año, con tres cargas de pastoreo, pesada, moderada y ligera. Los animales que disponian de harinolina diariamente durante el invierno, consumieron más sal y harina de hueso en la carga moderada $40 \%$ de uso de forraje producido) en relación a las otras dos. En la carga pesada consumieron menos harina de hueso. También las que consumieron harinolina en forma terciada (un día si y otro día no) pero en la carga moderada, consumieron más sal y harina de hueso que las otras dos cargas. Las vacas suplementadas con una mezcla de harinolina y sal ad libitum, ocuparon el segundo lugar en el consumo de harina de hueso y el último en el de sal, sin embargo, la cantidad total de sal consumida por dichos animales, fue el más alto.

For efficient production, breeding cattle grazing pine forest range in the South need salt and a highphosphorus supplement yearlong (Duncan and Epps, 1958). Stockmen often provide salt and steamed bonemeal ad libitum, but cattle may not always ingest sufficient quantities. Evidence of phosphorus deficiency among cattle having ac-

\footnotetext{
${ }^{1}$ Received September 8, 1969; accepted for publication November 29, 1969.
}

cess to bonemeal has been found (Black et al., 1949; Duvall and Hansard, 1967). Whether the cattle consume enough salt to satisfy their needs is problematic, since symptoms of mild deficiencies may escape detection.

This paper identifies factors associated with low intakes of salt and bonemeal furnished ad libitum to cowherds grazing forest range yearlong. Variables evaluated include season, grazing intensity, lactation, and method of feeding protein supplement.

\section{Methods}

The investigation was made in central Louisiana from October 1 , 1965, through September 28, 1967. Five contiguous range units, varying from 480 to 590 acres, were studied. When the trial began, three supported stands of artificially regenerated slash pines (Pinus el liottii) from 2 to 5 years old. The remaining units were sparsely stocked with second-growth long-

Herbage was similar on all ranges throughout the study. Slender bluestem (Andropogon tener) and pinehill bluestem ( $A$. divergens) were the main grasses. Other important forage plants included panicums leaf pines ( $P$. palustris).

(Panicum spp.), paspalums (Paspalum spp.), and miscellaneous bluestems. Annual production averaged about 2,000 lb/acre (air-dry). Small hardwood trees-principally blackjack and post oaks (Quercus marilandica and $Q$. stellata), southcrn and dwarf waxmyrtles (Myrica cerifera and $M$. pusilla), and shining sumac (Rhus copallina)-were widely scattered in some units and fairly abundant in others.

All units were grazed yearlong. Cows were typical "native" stock, as described by Duvall and Hansard (1967). Bulls were either Angus or Shorthorn. Cows were bred for late fall and winter calving. Calves were marketed directly off the cows between August 10 and 15.

Beginning in mid-January, grasslegume hay was furnished at 3 to 4 $\mathrm{lb} /$ head daily. Since range forage is seriously deficient in protein from fall until spring (Duvall and Hansard, 1967), cows and bulls were supplied $417 \mathrm{lb}$ each of cottonseed cake or meal $(41 \%$ crude protein) from November 1 through May. Cottonseed cake or meal allowances averaged:

Period.

Nov. 1 to 30

Dec. 1 to 31

Jan. 1 to March 10

March 11 to 31

April 1 to May 31

Two sets of three treatments each involved combinations of grazing intensities and feeding methods. In Set I, three range units were stocked for different grazing intensities: light, moderate, and heavy. All cattle grazing these units were fed cake daily in winter. In Set II, three units were grazed moderately, but cattle were fed by different methods: cake fed daily, cake fed on alternate days, and salt-meal mixture self-fed. One combination, moderate grazing and daily feeding, was common to both sets; hence, treatments totaled five.

For the three grazing intensities in Set $I$, average utilization percentages were 32,48 , and 57 . Herbage 
Table 1. Percent of herbage utilization for cattle fed cottonseed cake daily in winter.

\begin{tabular}{lccc}
\hline \multirow{2}{*}{ Grazing } & \multicolumn{3}{c}{ Year ending } \\
\cline { 2 - 4 } intensity & 1966 & 1967 & 1968 \\
\hline Light & 29 & 32 & 35 \\
Moderate & 44 & 52 & 47 \\
Heavy & 55 & 56 & 59 \\
\hline
\end{tabular}

use, measured by the caged-quadrat method of Duvall and Whitaker (1963), is shown by unit and year in Table 1. In these units, cattle werc fed on a schedule designated as daily because cake was distributed every day during the critical winter period, December 1 through March 31. In November, April, and May, they were fed on alternate days; a 2-day allowance was distributed at each feeding. Hay was provided daily from mid-January until new herbage was adequate.

In Set II, cattle grazing one unit were fed cake daily in winter as described for Set I. In another unit, the distribution schedule was designated as alternate-day, i.e., cake was supplied every other day from December 1 through March 10. A 2-day allowance was distributed at each feeding. During November and from March 11 through May 31, a 3-day allowance was distributed every third day. Hay was fed at the same frequency as cake. In the third unit, a mixture of one part salt to three parts meal (by weight), calculated to last for 2 or 3 days, was placed in bunks each year on November 1 (Duvall, 1969). After initial rate of consumption was determined, the mixture was adjusted until meal intake averaged about $1 \mathrm{lb} /$ cow-day. Thereafter, the proportion of salt was changed as necessary to attain prescribed intake of meal; the supply was replenished every 5 days. Hay feeding for the salt-meal treatment was the same as for alternate day feeding.

In all five units, steamed bonemeal (10\% phosphorus) and loose salt were provided yearlong in separate compartments of a covered feeder. These supplements, weighed after drying at $140 \mathrm{~F}$ until a constant weight was attained, were dispensed weekly. Each time, remainders were collected, dried, and weighed. Consumption was computed for 28-day periods by subtracting quantities recovered from those dispensed. By this method, intake by calves was indeterminable. Quantities consumed appeared relatively small, however, at feeders before early summer.

\section{Results}

\section{Salt Consumption}

Among cattle fed daily, salt consumption averaged grcatest for those on moderately grazed range (Table 2). Houston (1963) reported similar findings. Cattle on intermediately stocked range in Montana consumed more salt than those grazing at either heavier or lighter intensities; less available browse on the summer range stocked intermediately possibly accounted for that difference. In the present study, browse was most plentiful on the moderately grazed unit, but cattle ate little or none during summer.

Salt intake did not differ apprecisince calves were seldom observed ably between lightly and heavily

grazed units. It averaged $1.39 \mathrm{lb} /$ animal/28-day period for heavy use and $1.42 \mathrm{lb}$ for light.

Regardless of grazing intensity, cattle fed daily consumed the least salt during spring, when new herbage was most abundant. This finding generally agrees with those of Halls and Southwell (1954), Houston (1963), and Hughes and Southwell (1963).

Intake increased during summer but declined after calves were removed and lactation ceased in midAugust. This decrease was modest, suggesting that quantity eaten by the calves and the requirement for late lactation were not great.

Cattle on moderate and heavily grazed range consumed the most salt in fall. Cattle on lightly grazed range reached peak consumption considerably later; they ate more in winter than in fall.

On moderately grazed ranges, consumption was greatest for cattle fed on alternate days. Quantity taken annually from the free-choice supply was much less for cattle fed the salt-meal mixture than for those hand-fed cake. During the feeding season, cattle assigned to the saltmeal treatment consumed only 0.68 $\mathrm{lb} /$ head each 28 days, whereas cattle on other moderately grazed

Table 2. Average voluntary consumption (pounds) of salt per adult animal per 28-day period, 1965-66 and 1966-67.

\begin{tabular}{|c|c|c|c|c|c|}
\hline \multirow{2}{*}{$\begin{array}{l}\text { 28-day } \\
\text { period } \\
\text { ending }\end{array}$} & \multicolumn{5}{|c|}{ Grazing intensity and feeding method } \\
\hline & $\begin{array}{l}\text { Light- } \\
\text { daily }\end{array}$ & $\begin{array}{l}\text { Heavy- } \\
\text { daily }\end{array}$ & $\begin{array}{c}\text { Moderate- } \\
\text { daily }\end{array}$ & $\begin{array}{c}\text { Moderate- } \\
\text { alternate-day }\end{array}$ & $\begin{array}{l}\text { Moderate- } \\
\text { salt-meal }\end{array}$ \\
\hline $10 / 28$ & 1.15 & 1.60 & 3.19 & 2.63 & 2.66 \\
\hline $11 / 25$ & 1.68 & 1.40 & 2.77 & 3.18 & 1.77 \\
\hline $12 / 23$ & 1.83 & 1.38 & 1.56 & 3.18 & 0.68 \\
\hline $1 / 20$ & 1.86 & 1.50 & 1.38 & 2.66 & 0.24 \\
\hline $2 / 17$ & 1.64 & 1.38 & 1.50 & 2.04 & 0.36 \\
\hline $3 / 17$ & 1.64 & 1.18 & 1.20 & 1.71 & 0.72 \\
\hline $4 / 14$ & 1.14 & 1.08 & 0.78 & 1.23 & 0.30 \\
\hline $5 / 12$ & 0.88 & 0.98 & 1.06 & 1.55 & 0.57 \\
\hline $6 / 9$ & 1.49 & 1.15 & 1.89 & 1.87 & 1.92 \\
\hline $7 / 7$ & 1.13 & 1.43 & 2.40 & 2.08 & 2.36 \\
\hline $8 / 4$ & 1.56 & 1.73 & 2.53 & 2.07 & 2.80 \\
\hline $9 / 1$ & 1.18 & 1.60 & 1.96 & 1.94 & 1.74 \\
\hline $9 / 29$ & 1.25 & 1.61 & 2.03 & 1.92 & 1.90 \\
\hline Total & 18.43 & 18.02 & 24.25 & 28.06 & 18.02 \\
\hline Average & 1.42 & 1.39 & 1.87 & 2.16 & 1.39 \\
\hline
\end{tabular}


Table 3. Average consumption (lb) of bonemeal per adult animal per 28-day period, 1965-66 and 1966-67.

\begin{tabular}{|c|c|c|c|c|c|}
\hline \multirow{2}{*}{$\begin{array}{l}28 \text {-day } \\
\text { period } \\
\text { ending }\end{array}$} & \multicolumn{5}{|c|}{ Grazing intensity and feeding method } \\
\hline & $\begin{array}{l}\text { Light- } \\
\text { daily }\end{array}$ & $\begin{array}{l}\text { Heavy- } \\
\text { daily }\end{array}$ & $\begin{array}{l}\text { Moderate- } \\
\text { daily }\end{array}$ & $\begin{array}{l}\text { Moderate- } \\
\text { altcrnatc-day }\end{array}$ & $\begin{array}{l}\text { Moderate- } \\
\text { salt-mcal }\end{array}$ \\
\hline $10 / 28$ & 0.84 & 1.42 & 2.02 & 3.56 & 3.37 \\
\hline $11 / 25$ & 1.65 & 1.00 & 1.42 & 3.32 & 3.76 \\
\hline $12 / 23$ & 0.92 & 0.87 & 0.80 & 2.24 & 1.97 \\
\hline $1 / 20$ & 1.48 & 0.74 & 0.70 & 2.74 & 1.06 \\
\hline $2 / 17$ & 0.78 & 0.76 & 0.44 & 1.85 & 0.88 \\
\hline $3 / 17$ & 1.04 & 0.54 & 0.94 & 1.50 & 1.27 \\
\hline $4 / 14$ & 0.76 & 0.54 & 0.41 & 0.62 & 0.44 \\
\hline $5 / 12$ & 0.24 & 0.27 & 0.72 & 1.00 & 0.54 \\
\hline $6 / 9$ & 1.40 & 0.54 & 2.08 & 2.01 & 1.97 \\
\hline $7 / 7$ & 1.24 & 0.92 & 2.80 & 3.36 & 3.46 \\
\hline $8 / 4$ & 1.60 & 1.49 & 3.13 & 4.64 & 3.74 \\
\hline $9 / 1$ & 1.46 & 1.36 & 1.95 & 3.61 & 2.36 \\
\hline $9 / 29$ & 0.87 & 0.98 & 1.80 & 2.84 & 2.84 \\
\hline Total & 14.28 & 11.43 & 19.21 & 33.29 & 27.66 \\
\hline Average & 1.10 & 0.88 & 1.48 & 2.56 & 2.13 \\
\hline
\end{tabular}

ranges averaged $1.93 \mathrm{lb}$. Even so, voluntary intake by the self-fed herd was surprisingly high, because large quantities of salt were also ingested from the salt-meal mixture. During November through May intake from the latter source ranged from 8 to $34 \mathrm{lb} /$ head/28 days and averaged $146 \mathrm{lb} /$ head annually. When meal or cake was not furnished, the self-fed cattle voluntarily consumed about the same quantities as cattle on other moderately grazed ranges-1.99 and 2.08 lb/head/28 days.

For cattle fed on alternate days or supplied salt-meal mixture, as for those fed daily, voluntary intake was lowest in spring. Intake increased during summer and diminished after calves were weaned. Peak intake was in October for cattle fed daily, in November and December for those fed on alternate days, and in July for those fed the salt-meal.

\section{Bonemeal Consumption}

Among cattle fed daily, bonemeal consumption was greatest for those grazing moderately and least for those grazing heavily (Table 3). Thus, the rankings were the same as for salt intake. Annual intake on moderately grazed range aver- aged about $19 \mathrm{lb} /$ adult animal. Duvall and Whitaker (1963) reported $29 \mathrm{lb}$ for cattle fed daily on similar range that was $35 \%$ utilized. In that investigation, however, grass hay was fed and cottonseed cake allowance was only $373 \mathrm{lb}$. In the present study, the grass-legume hay and the 44-1b increase in cake provided additional phosphorus.

On moderately grazed ranges, cattle fed on alternate days ate the most bonemeal yearlong and those self-fed the salt-meal ranked second. The difference was greatest during the feeding season, when cattle fed on alternate days consumed 1.3 times as much as those that were sclf-fcd. During the remainder of the year the alternate-day-fed herd averaged only 1.1 times as much. by treatment, calving percentage, and year.
Bonemeal consumption on moderately grazed range was least for the cattle fed daily. Most of the difference was accounted for during the feeding season, when intakes for alternate-day and salt-meal treatments were 2.6 and 1.9 times greater than for daily feeding. During the remainder of the year differences were much less.

For all treatments, bonemeal intake was generally least between mid-March and mid-May. Although phosphorus content of herbage is usually highest during this season, the main species are deficient for lactating cows (Duncan and Epps, 1958). Quantity ingested increased steadily from May until early August, when intake was at or near peak levels. Calves were weaned shortly afterward and consumption subsequently declined. By October or November, herbage had matured and phosphorus content was undoubtedly inadequate for dry cows; Campbell et al. (1954) found that the main bluestem grasses contained less than $0.07 \%$ at this stage. Bonemeal intake increased after herbage matured but declined after December 1, since the 2.5-lb daily allowance of cottonseed meal or cake furnished considerable phosphorus.

\section{Lactation Effects on Mineral Intake}

Lactating cows require more sodium, chlorine, and phosphorus than nonlactating cows (Morrison, 1943; NAS-NRG, 1963). Although reproductive rate, and therefore the proportion of lactating cows, varied considerably among both treat-

Table 4. Voluntary consumption (Ib) of salt and bonemeal per 28-day period,

\begin{tabular}{|c|c|c|c|c|c|c|}
\hline \multirow{2}{*}{$\begin{array}{l}\text { Grazing intensity } \\
\text { and feeding } \\
\text { method }\end{array}$} & \multicolumn{2}{|c|}{$\begin{array}{c}\text { Calving } \\
\text { percentage }\end{array}$} & \multicolumn{2}{|c|}{$\begin{array}{c}\text { Salt } \\
\text { intake }\end{array}$} & \multicolumn{2}{|c|}{$\begin{array}{l}\text { Bonemeal } \\
\text { intake }\end{array}$} \\
\hline & $1965-66$ & $1966-67$ & $1965-66$ & $1966-67$ & $1965-66$ & $1966-67$ \\
\hline Light-daily & 69 & 76 & 1.31 & 1.53 & 0.92 & 1.28 \\
\hline Heavy-daily & 58 & 68 & 1.38 & 1.39 & 0.94 & 0.82 \\
\hline Moderate-daily & 63 & 75 & 1.83 & 1.90 & 1.45 & 1.50 \\
\hline $\begin{array}{l}\text { Moderate-alternat } \\
\text { day }\end{array}$ & 43 & $\begin{array}{l}95 \\
69\end{array}$ & 2.18 & $\begin{array}{l}2.13 \\
149\end{array}$ & $\begin{array}{r}2.45 \\
1.86\end{array}$ & $\begin{array}{l}2.67 \\
940\end{array}$ \\
\hline
\end{tabular}


ments and years, it apparently was not a major factor influencing intake of bonemeal or salt (Table 4).

\section{Discussion and Conclusion}

Under conditions of this trail, cattle on ranges stocked to utilize about $48 \%$ of current herbage ate more salt and bonemeal than cattle on ranges grazed at either heavier or lighter intensity. Bonemeal intake by the herd on heavily grazed range was especially low, averaging only $60 \%$ as much as for cattle grazing at moderate intensity. No reason for this difference was apparent. Cook et al. (1953) reported that as utilization by sheep on Utah range increased, phosphorus in residual forage diminished. It was expected, therefore, that cattle on Louisiana range would react similarly, increasing intake of bonemeal as grazing intensity increased. The drastic departure from the expectation could imply that intense grazing caused cattle to utilize plants low in palatability but high in phosphorus; however the supply of such forages was meager, especially from midsummer until spring.

Among cattle on moderately grazed ranges, bonemeal consumption and voluntary intake of salt were greatest for those fed cake on alternate days during winter. Duvall (1969) reported evidence that this method of protein supplementation stimulated grazing, and the eating of mineral supplements may have been similarly affected. As compared to daily feeding, the self-feeding of salt-meal mixture also apparently stimulated bonemeal consumption.

The self-fed cattle ranked lowest in voluntary intake of salt but highest in total quantity consumed. Although salt eaten with the meal greatly exceeded requirements, voluntary intake continued throughout the feeding season. The animals had obtained salt ad libitum before the study began and had apparently established a habit that persisted, despite the newly created source. Reynolds and Lindahl (1969) concluded that quantity of salt ingested ad libitum by sheep depended to some extent on the level to which they had become accustomed. For whatever reason, the yearlong intake from the freechoice supply in the present study discredits the widespread belief that cattle will voluntarily take only needed amounts of salt.

\section{Literature Cited}

Black, W. H., L. H. Tash, J. M. Jones, ANd R. J. Kleberg, Jr. 1949. Comparison of methods of supplying phosphorus to range cattle. U.S. Dep. Agr. Tech. Bull. 981, 22 p.

Campbell, R. S., E. A. Epps, JR., C. C. Moreland, J. L. FarR, and F. BonNER. 1954. Nutritive values of native plants on forest range in central Louisiana. La. Agr. Exp. Sta. Bull. $488,18 \mathrm{p}$.

CoOK, C. W., L. A. STOdDART, AND L. E. Harris. 1953. Effects of grazing intensity upon the nutritive value of range forage. J. Range Manage. 6: 51-54.

Duncan, D. A., and E. A. Epps, JR. 1958. Minor mineral elements and other nutrients on forest ranges in central Louisiana. La. Agr. Exp. Sta. Bull. 516, 19 p.

DuvalL, V. L. 1969. Comparison of supplementation methods for cow herds grazing pine-bluestem range. J. Range Manage. 22:182-187.

Duvall, V. L., and S. L. Hansard. 1967. Responses of southern range cattle to protein supplementation. J. Range Manage. 20:153-157.

Duvall, V. L., AND L. B. Whitaker. 1963. Supplemental feeding increases beef production on bluestemlongleaf pine ranges. La. Agr. Exp. Sta. Bull. 564, 18 p.

Halls, L. K., and B. L. Southwell. 1954. Consumption of minerals by cattle on southeastern Coastal Plain forest range. J. Range Manage. 7: 163-165.

Houston, W. R. 1963. Salt consumption by breeding cows on native range in the northern Great Plains. J. Range Manage. 16:12-16.

Hughes, R. H., AND B. L. Southwell. 1963. Mineral consumption related to improved cattle management systems in Georgia. J. Range Manage. 16:109-113.

MoRrison, F. B. 1943. Feeds and feeding. 20th ed. The Morrison Publishing Co., Ithaca, N.Y. $1050 \mathrm{p}$.

National Academy of Sciences-National Research Council. 1963. Nutrient requirements of beef cattle. Publication 1137, $30 \mathrm{p}$.

Reynolds, P. J., and I. L. Lindahl. 1969. Effects of pelleting of forage on the ad libitum salt and water consumption and urine excretion of sheep. J. Anim. Sci. 28:563-567.

1971 SUMMER MEETING

Rapid City, South Dakota

July 29-31, 1971 